\title{
Identification of Regression Model for Crime Rate and Literacy Rate in India
}

\author{
Nandkumar Bodhgire ${ }^{1}$ and Aniket Muley $^{2 *}$ \\ ${ }^{1}$ School of Social Sciences, S.R.T.M. University, Nanded-431606, India \\ ${ }^{2}$ School of Mathematical Sciences, S.R.T.M. University, Nanded-431606, India \\ n99bodhgire@gmail.com, aniket.muley@gmail.com*
}

\begin{abstract}
This paper mainly focuses on crime rate and literacy in India. Crime Rate in India is reported 385.5 in 2019 which has been increasing by upward trend since 1980 as per the data provided by National Crime Records Bureau, Ministry of Home Affairs, and Government of India. An attempt is made to find the relationship between the crime rate and literacy rate in states and union territories through a regression model. The result shows that Strength of association is even though less it indicates a positive relationship between literacy rate and IPC, SLL and Crime against Children.
\end{abstract}

Keywords: Crime rate; IPC; SLL; Literacy rate; Regression

\section{Introduction:}

In India, there is unrest among youth, peasants, industrial workers, students, government employees, women, scheduled caste, scheduled tribe and the minorities. This unrest increases frustrations and strains which lead to the violation of legal and social norms. Negeri and Kumar (2015) observed that, income inequality creates social polarization in society. Crime Rate in India is reported 385.5 in 2019 which has been increasing by upward trend since 1980 as per the data provided by National Crime Records Bureau, Ministry of Home Affairs in the form of volume I, II and III. It is observed that, 51,56,172 cognizable crimes are registered of which 32,25,701 have come under Indian Penal Code (IPC) crime and remaining 19,30,471 are the part of Special and Local Laws (SLL) crime in 2019. IPC falls under theft, burglary, robbery, dacoit, murder, riot, kidnapping, cheating, and breach of trust crime. Similarly, Special and Local Laws (SLL) falls under Dowry Prohibition Act, 1961, Prohibition of Child Marriage Act 2006, SC/ST (Prevention of Atrocities) Act, 1989, Offences against the state, Arms Act 1959, Intellectual Property act, Liquor \& Narcotic Drug-related act etc.

Negeri and Kumar (2015) focused on Social Polarization and Urbanization in India. The author found that urbanized states have an organized and unorganized occupational structure which increases income inequality in the society by which social disputes and crime rates are raised. Urbanization for economic development creates social polarization in India. They have performed statistical analysis and found that developed states have high per cent inequality in Income and violence. Gonazalez (2015) highlighted that most of the researchers from social sciences have analyzed the root of crime from different angles country-bycountry. They found that there is an inverse relationship between college graduation rate and 
crime rate. Hansen (2003), Lochner and Moretti (2004) performed empirical study and explored the significant relationship between schooling and criminal participation using three data sources: individual-level, state-level data on arrests, and self-report data on crime and incarceration from the National Longitudinal Survey of Youth. Finding is Schooling significantly reduces criminal activities.

Gupta and Sachdeva (2017) investigated the relationship between various economic, demographic and deterrent factors with the crime rate in India using the data of all the Indian states and union territories of period 2011. It is observed in their study that variables like population density, sex ratio, minority population, poverty, per capita income, no of police personnel and literacy rate on crime etc are crucial determinants of the rate of the criminal cases registered in India. Moretti (2005) concluded that the impact of education on crime implies that there are benefits to education not taken into account by individuals themselves, so the social return to schooling is larger than the private return. Lance Lochner (2007) concluded that when making their schooling decisions, youth may not consider the important negative costs they impose on society if they choose to drop out of high school in favour of a life of crime. Lochner and Moretti (2004); Anderson (2009); Hjalmarsson et al. (2011) observed that education policies can reduce property crime as well as violent crime. In both the US and Sweden, the estimated effects of educational attainment or school enrollment on property and violent offences appear to be quite similar in percentage terms. Cullen (2006) highlighted that education based policies need not increase educational attainment to reduce crime. Studies performed on student's admission in the school, if it based on the lottery system then it having major disadvantage. Further, it is observed that, in urban region youth with better schools can substantially reduce juvenile and adult crime. Rud and Klaveren (2013) performed review on education and youth crime. They suggested that early-childhood program improve the educational outcomes of children and reduce the criminal behavior of youth people from disadvantaged families. Hjalmarsson et al. (2015) studied the effect of educational attainment on conviction and incarceration taking data from Sweden's Multigenerational Registrar through ordinary least square method. They found significant negative effect of schooling on male convictions and incarceration. One additional year of school decreases the likelihood of conviction by $6.7 \%$ and incarceration by $15.5 \%$. Tekeli and Gunsoy (2013) explained the relation between education and economic crime taking data from Turkish statistical Institution during 1990-2011. Further, they have analyzed relationship between age, marital status, education level and occupation and the types of crime are investigators through descriptive analysis.

Education is one of the crucial Components through which human life along with the standard of living can be improved. Education teaches people how to behave with society. In short, there will not be any disturbances in a society like riots, war, bloodshed, crime, etc. Education has abolished all traditional customs, bad habits in the society which are being followed by the society last two decades. Hence, there is an inverse relationship exist with the crime rate and education in India. The literacy rate is an indicator of education. If literacy rate increase, crime rate should be decreased or if the literacy rate decrease, crime rate should be increased. But this hypothetical statement was applicable when India firstly started education. 
Recently, although the literacy rate in India has an average of $80 \%$ yet crimes are not abolished from society therefore, it needs to be discussed the relationship between crime and literacy. It is expected from educated persons in society that to give proper knowledge regarding what is wrong and good to society so everyone will follow the rules of human living for improving themselves and will exist peacefulness everywhere. There will not be any internal or international conflict among states and countries. These conflicts destroy society as a result crime take place in large number. Crime is a very crucial issue is not only restricted upto India but also throughout all over the world. A low crime rate is one of the indicators of a developed country. There are many factors which affect the crime rate observed in the undeveloped countries. Poverty, unemployment, education, drug abuse by youth, the mental condition of people in the society and health status are also influencing on crime. India is an underdeveloped country where all the above problems are being faced consistently.

In this study, our main objective is to identify the regression model between crime rate and literacy rate in India. Also, to study what kind of crime is increasing in India. The null hypothesis is considered in this study, there is no relationship between Crime Rate and Literacy Rate in India against the relationship between Crime Rate and Literacy Rate in India.

\section{Methodology}

This study is mainly depends on the secondary data. Crime rate and Literacy rate is the major two variables in which contain IPC and SLL data and is collected from Statistics Volume, Crime in India 2019, published by National Crime Records Bureau, Ministry of Home Affairs under Government of India. The present study is descriptive and analytical in nature. Crime rate and Literacy rate is the major two key variables in which contain literacy rate of all states in India and crimes recoded in terms of IPC and SLL in 2019. The statistical tools that have been employed in the study include arithmetic mean, standard deviation and Analysis of Variance (ANOVA). State-wise Crime rate and Literacy rate is analyzed through a regression model.

\section{Result and discussion}




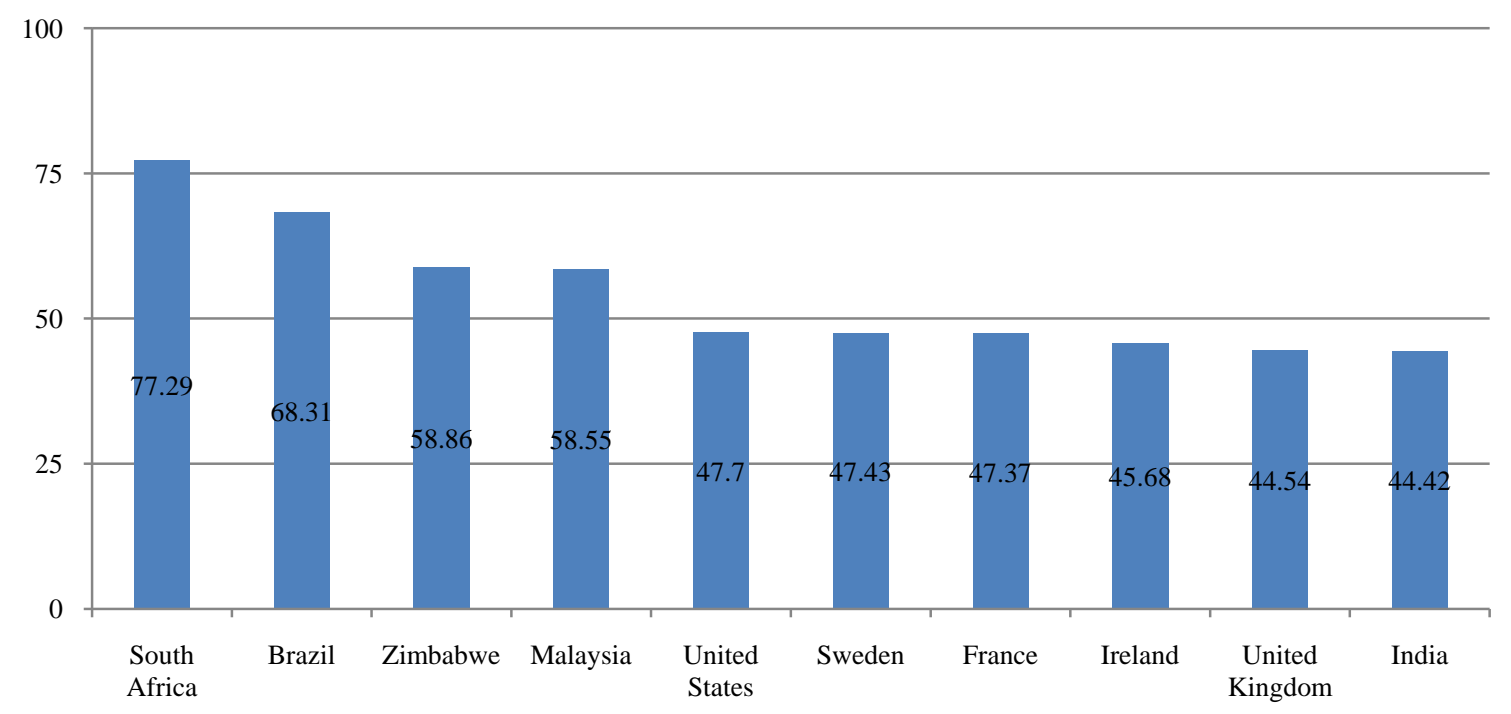

Fig. 1 Country wise Crime Index

Fig. 1 explores the first ten rank countries having highest crime rates in world. It is observed that, South Africa, Brazil, Zimbabwe, Malaysia, United States, Sweden, France, Ireland, the United Kingdom and India having high crime rate. Fig. 1 reveals that, crime rates are high not only in the poorest continent but also in the richest continent in the world. Particularly, France, Sweden, the United Kingdom and Ireland have developed countries but having more crime also. India's crime rate is also high but as compared with developed countries it is less.

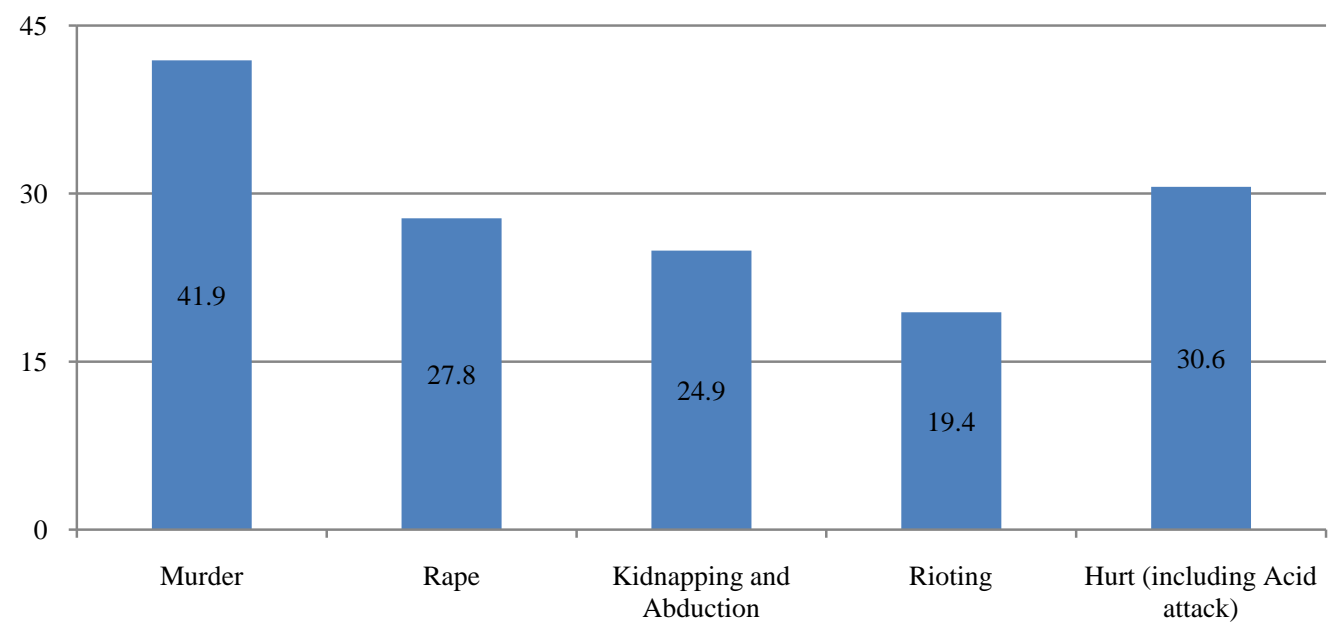

Fig. 2 Conviction rate under IPC 


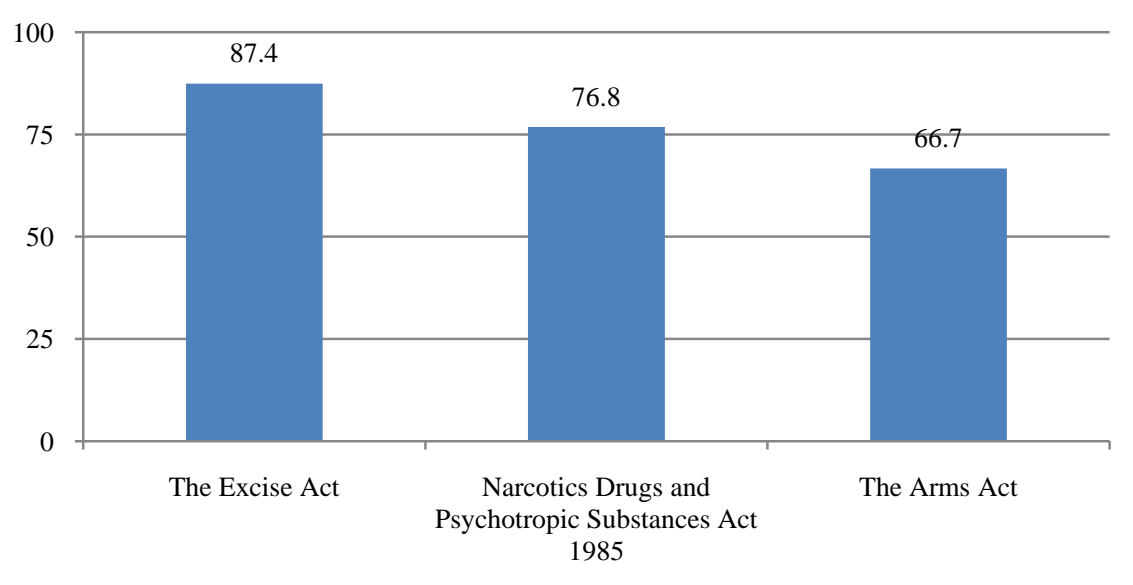

Fig. 3 Conviction Rate under SLL

Fig. 2 represents conviction rate under IPC in India and the highest crime is murder, followed by hurt and rape. Crime under SLL, Motor vehicle act crime is more than the excise act and Narcotics Drugs and Psychotropic Substances Act, 1985 (Fig. 3). These crime cases are indicated disposal of IPC and SLL cases by police and court as per the data reported in the National Crime Records Bureau, Ministry of Home Affairs. The most important crimes are recorded under IPC which are: violent crime including murder, rape and kidnapping, property crimes including theft and burglary, a crime against women, economic crimes including cheating, breach of trust, counterfeiting, remaining crime are related with SC/ST communities, children, cybercrime etc. Crimes under SLL, crime is concerned to prohibition act, gambling act, excise act and remaining are concerned to Immoral Traffic Act, Narcotic Drugs Acts, Explosives Act, Dowry Prohibition Act, Essential Commodities Act, TADA, and so on. 


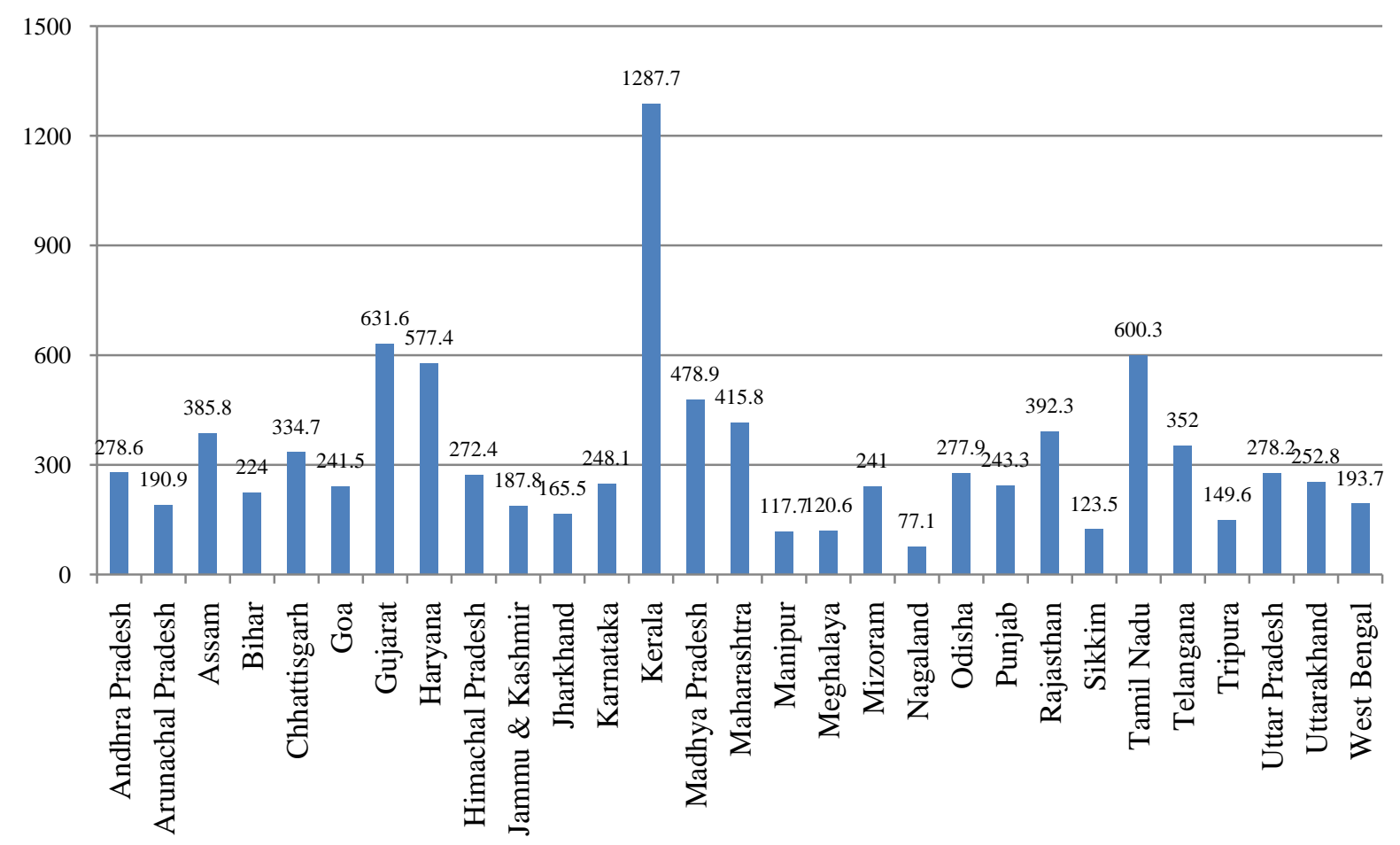

Fig. 4 State-wise Cognizable Crimes (IPC and SLL) in India 2019

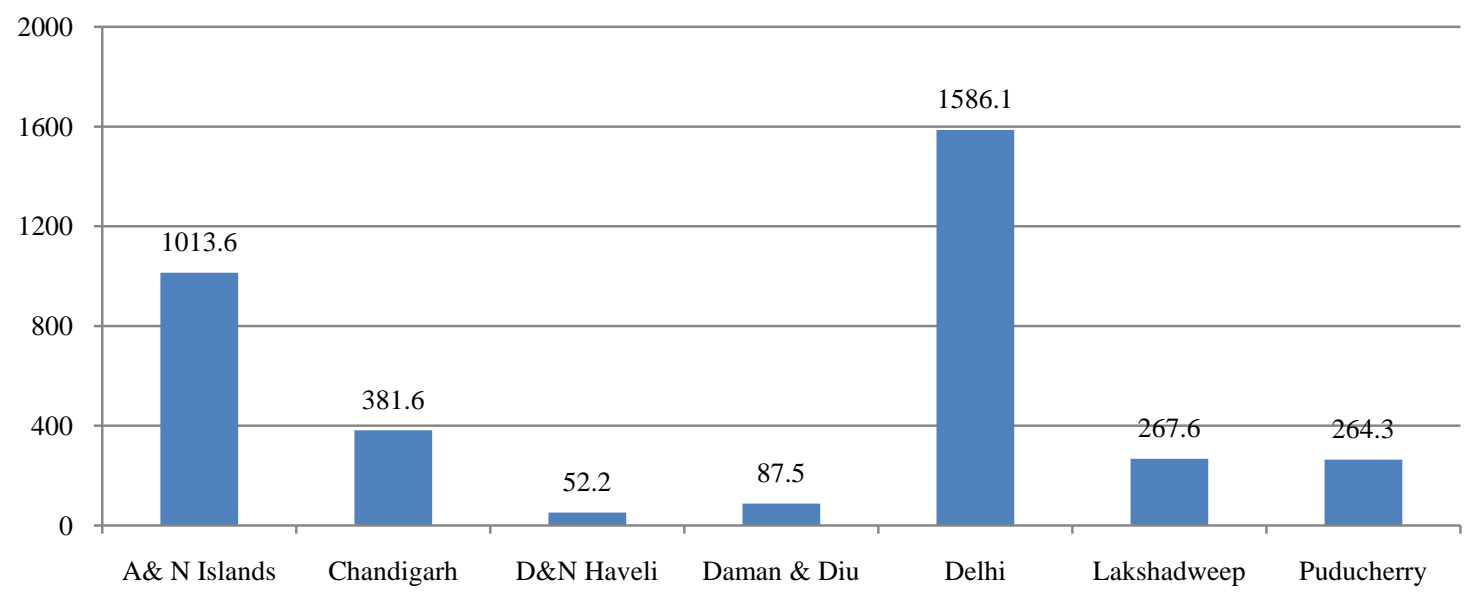

Fig. 5 Rate of Cognizable Crimes (IPC + SLL)

According to NCRB, Government of India's published crime report 2019; it is observed that, 62.6 per cent of the total cognizable crimes are associated with IPC crime whereas 37.4 per cent was concerned to SLL crime.

Data report of National Crime Records Bureau highlighted that educated states having higher crime rate like, Delhi (1586.1), A\&N Islands (1013.6), Kerala (1287.7), Tamil Nadu (600.3), Gujrat (631.6), Haryana (577), Maharashtra (415.8), and Madhya Pradesh (478.9) (See Fig. 5). Delhi and $A \& N$ Islands is the most educated states in union territories where literacy rate 
recorded 86.34 and 86.27 respectively. According to data report by NCRB, in 2019 rate of cognizable Crimes (IPC+SLL) recorded for Delhi (1586.1) and for A\&N Islands (1013.6) which is higher among union territories (Fig. 4). Similarly, Kerala, Tamil Nadu and Maharashtra have a literacy rate of more than $80 \%$ but at the same time, criminal cases are also registered more in 2019. Therefore, taking into account the figure of literacy rate and crime rate in various states, it finds that there is no correlation between these variables. This is a general statement. It needs to be proved at a statistically significant level. Therefore, this study applies the correlation and regression analysis method for analyzing the relationship between literacy rate and crime rate in India taking secondary data from NCRB Report which is published by the Ministry of Home Affairs.

\section{Literacy Rate in India}

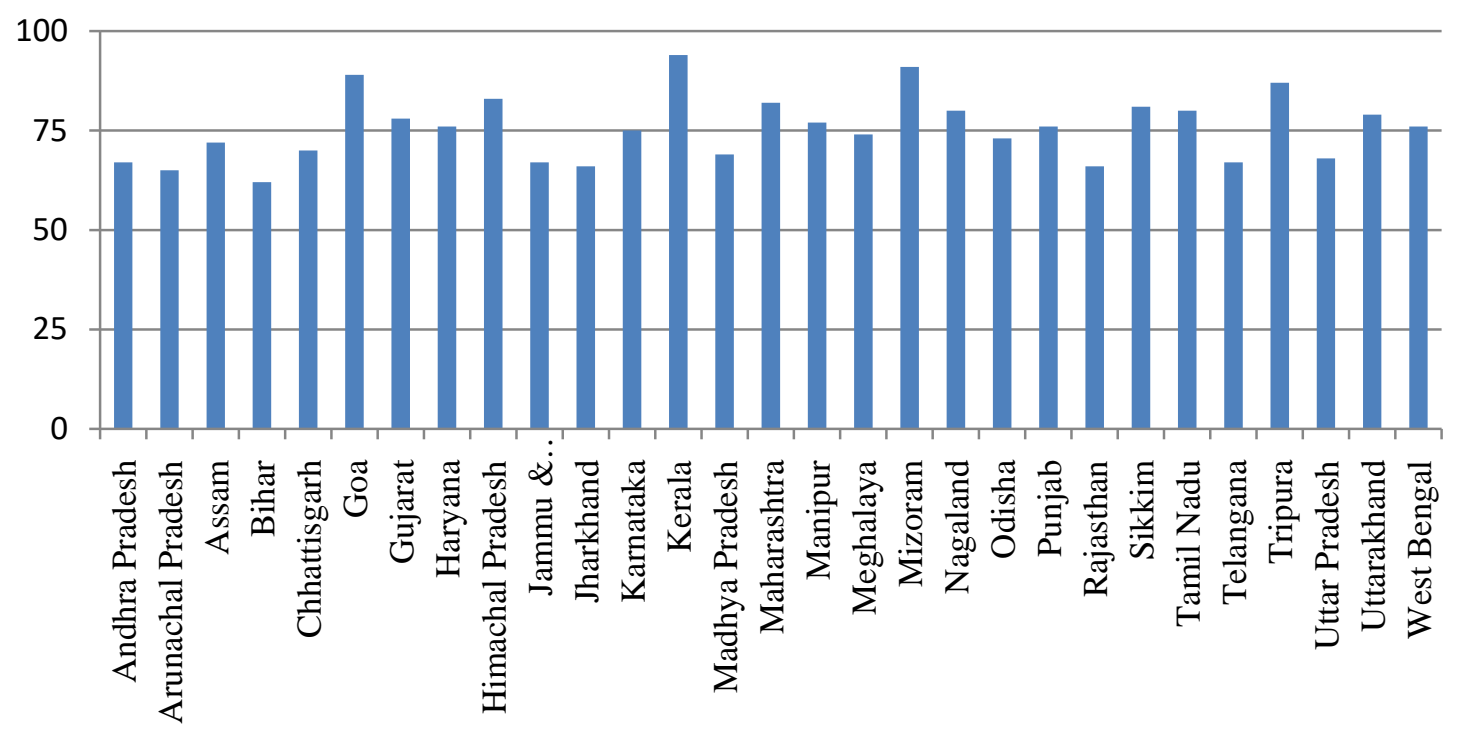

Fig. 6 Literacy Rate

Fig. 6 represents state wise literacy rate in India. It is clearly observed that Kerala state is having highest literacy rate then followed by Mizoram, Goa, Tripura, Himachal Pradesh and Maharashtra.

\section{Results:}

Table 1 Model Summary

\begin{tabular}{lcccc}
\hline Model & $\mathrm{R}$ & $\mathrm{R}^{2}$ & Adj. R $^{2}$ & $\begin{array}{c}\text { Std. Error of } \\
\text { the Estimates }\end{array}$ \\
\hline Literacy rate and Indian Penal Code (IPC) & .405 & .164 & .133 & 151.40324 \\
Literacy Rate and Special and Local Law Rate (SLL) & .331 & .110 & .084 & 186.81364 \\
Literacy Rate and Crime rate (IPCSLLR) & .313 & .098 & .071 & 313.67468 \\
Literacy Rate and Crime Rate against Children (CC) & .422 & .178 & .154 & 29.83724 \\
\hline
\end{tabular}


Table 2 ANOVA Table

\begin{tabular}{|c|c|c|c|c|c|}
\hline \multicolumn{6}{|c|}{ Literacy rate and Indian Penal Code (IPC) } \\
\hline Model & Sum of Squares & df & Mean Square & $\mathrm{F}$ & Sig. \\
\hline Regression & 121106.595 & 1 & 121106.595 & 5.283 & 0.030 \\
\hline Residual & 618919.426 & 27 & 22922.942 & & \\
\hline Total & 740026.021 & 28 & & & \\
\hline \multicolumn{6}{|c|}{ Literacy Rate and Special and Local Law Rate (SLL) } \\
\hline Regression & 146279.079 & 1 & 146279.079 & 4.191 & 0.048 \\
\hline Residual & 1186577.366 & 34 & 34899.334 & & \\
\hline Total & 1332856.446 & 35 & & & \\
\hline \multicolumn{6}{|c|}{ Literacy Rate and Crime rate (IPCSLLR) } \\
\hline Regression & 363192.003 & 1 & 363192.003 & 3.691 & 0.063 \\
\hline Residual & 3345321.274 & 34 & 98391.802 & & \\
\hline Total & 3708513.276 & 35 & & & \\
\hline \multicolumn{6}{|c|}{ Literacy Rate and Crime Rate against Children (CC) } \\
\hline Regression & 6567.405 & 1 & 6567.405 & 7.377 & 0.010 \\
\hline Residual & 30268.865 & 34 & 890.261 & & \\
\hline Total & 36836.270 & 35 & & & \\
\hline
\end{tabular}

Table 3 Regression Model Summary

\begin{tabular}{|c|c|c|c|c|c|}
\hline \multicolumn{6}{|c|}{ Literacy rate and Indian Penal Code (IPC) } \\
\hline \multirow{2}{*}{$\begin{array}{l}\text { Coefficients } \\
\text { Model }\end{array}$} & \multicolumn{2}{|c|}{ Unstandardized Coefficients } & \multirow{2}{*}{$\frac{\text { Standardized Coefficients }}{\text { Beta }}$} & \multirow[b]{2}{*}{$\mathrm{t}$} & \multirow[b]{2}{*}{ Sig } \\
\hline & $\mathrm{B}$ & Std. Err & & & \\
\hline (Constant) & -481.853 & 262.260 & & -1.837 & .077 \\
\hline IPC & 7.931 & 3.450 & .405 & 2.299 & .033 \\
\hline \multicolumn{6}{|c|}{ Literacy Rate and Special and Local Law Rate (SLL) } \\
\hline \multirow{2}{*}{$\begin{array}{l}\text { Coefficients } \\
\text { Model }\end{array}$} & \multicolumn{2}{|c|}{ Unstandardized Coefficients } & Standardized Coefficients & \multirow[b]{2}{*}{$\mathrm{t}$} & \multirow[b]{2}{*}{ Sig } \\
\hline & $\mathrm{B}$ & Std. Err & Beta & & \\
\hline (Constant) & -445.812 & 282.865 & & -1.576 & .124 \\
\hline LR & 7.416 & 3.622 & .331 & 2.047 & .048 \\
\hline \multicolumn{6}{|c|}{ Literacy Rate and Crime rate (IPCSLLR) } \\
\hline Coefficients & \multicolumn{2}{|c|}{ Unstandardized Coefficients } & Standardized Coefficients & \multirow[b]{2}{*}{$\mathrm{t}$} & \multirow[b]{2}{*}{ Sig } \\
\hline Model & $\mathrm{B}$ & Std. Err & Beta & & \\
\hline (Constant) & -553.348 & 478.735 & & -1.156 & .256 \\
\hline LR & 11.789 & 6.136 & .313 & 1.921 & .063 \\
\hline \multicolumn{6}{|c|}{ Literacy Rate and Crime Rate against Children (CC) } \\
\hline \multirow{2}{*}{$\begin{array}{l}\text { Coefficients } \\
\text { Model }\end{array}$} & \multicolumn{2}{|c|}{ Unstandardized Coefficients } & Standardized Coefficients & \multirow[b]{2}{*}{$\mathrm{t}$} & \multirow[b]{2}{*}{ Sig } \\
\hline & $\mathrm{B}$ & Std. Err & Beta & & \\
\hline (Constant) & -79.927 & 45.538 & & -1.755 & .088 \\
\hline LR & 1.585 & .584 & .422 & 2.716 & .010 \\
\hline
\end{tabular}

Table 1 explores the model summary of the data. The data reveals that, 0.40 correlation between Literacy rate and special and local law rate (SLL); 0.31 correlation between Literacy rate and Indian Penal code and special and local law rate (IPCSLL) and 0.42 correlation between crime rate against children and literacy rate respectively.

Thus the value of coefficient of determination or the strength of association between crime rate and literacy rate is $16.4 \%$. The value of coefficient of determination or the strength of association between crime rate and literacy rate is $0.098 \%$. The value of coefficient of determination or the strength of association between crime rate and literacy rate is $0.17 \%$. There is low association between these two variances. 
Table 2 explores the one way ANOVA summary of the data. It showed that, in all the cases viz., SLL, SLL, IPCSLLR and CC. It is observed that, except Literacy Rate and Crime rate (IPCSLLR) remaining all the cases is found to be significant. Table 3 explores the regression model summary of the data. It is observed that, for three of the cases, the value of regression coefficient indicates positive relationship with statistical significance level. Slope coefficient is with significant. It is reliable predict literacy rate on special and local law rate.

\section{Conclusion}

There is positive correlation between literary rate and crime rate in India. Higher educated states having high crime rate in India. Crimes under special and local laws are reported more in the states. India's crime rate is less than other countries. States found where more crime under IPC and SLL: Kerala, Gujarat, Tamil Nadu, Haryana, Madhya Pradesh and Maharashtra respectively. Educated union territories have more crime like Delhi and A \& N Islands. Kerala is one of the highest educated states where reported highest crime rate also.

According to NCRB report in 2019 rate of cognizable Crimes Indian Penal Code along with Special and Local Laws recorded for Delhi (1586.1) and for A\&N Islands (1013.6) which is higher among union territories. Similarly, it is observed that, Kerala, Tamil Nadu and Maharashtra have a literacy rate of more than $80 \%$ but at the same time, criminal cases are also registered more in 2019. Crime rate may be decreased if the education level increases in the society.

\section{References}

[1] Buonanno, P., \& Leonida, L. (2006). Education and crime: evidence from Italian regions. Applied Economics Letters, 13(11), 709-713.

[2] Cullen, J. B., Jacob, B. A., \& Levitt, S. (2006). The effect of school choice on participants: Evidence from randomized lotteries. Econometrica, 74(5), 1191-1230.

[3] Cunha, F., \& Heckman, J. (2007). The technology of skill formation. American Economic Review, 97(2), 31-47.

[4] Cunha, F., Heckman, J. J., Lochner, L., \& Masterov, D. V. (2006). Interpreting the evidence on life cycle skill formation. Handbook of the Economics of Education, 1, 697-812.

[5] Currie, J. (2001). Early childhood education programs. Journal of Economic perspectives, 15(2), 213-238.

[6] Deković, M., Asscher, J. J., Slagt, M. I., \& Boendermaker, L. (2012). Prevention programmes in early and middle childhood and their effect on adult crime. Persisters and desisters in crime from adolescence into adulthood. Explanation, prevention and punishment, 239-262.

[7] Deming, D. (2009). Early childhood intervention and life-cycle skill development: Evidence from Head Start. American Economic Journal: Applied Economics, 1(3), 111-34.

[8] Desilver, D. (2014). College enrollment among low-income students still trails richer groups. Pew Research Center, 15.

[9] Draca, M., \& Machin, S. (2015). Crime and economic incentives. economics, 7(1), 389-408.

[10] Dreze, J., \& Khera, R. (2000). Crime, gender, and society in India: Insights from homicide data. Population and development review, 26(2), 335-352. 
[11] Dubey and Aggarwal (2015) Crime, Crime Rates and Control Techniques: A Statistical Analysis: https://www.lawctopus.com/academike/crime-crime-rates/

[12] Dutta, M., \& Husain, Z. (2009). Determinants of crime rates: Crime Deterrence and Growth in postliberalized India.

[13] Erten, B., \& Keskin, P. (2019). Compulsory schooling for whom? The role of gender, poverty, and religiosity. Economics of Education Review, 72, 187-203.

[14] Farrington, D. P., Gallagher, B., Morley, L., St. Ledger, R. J., \& West, D. J. (1986). Unemployment, school leaving, and crime. The British Journal of Criminology, 26(4), 335-356.

[15] Freeman, R. (1983). Crime and unemployment. Crime and public policy.

[16] Freeman, R. B. (1996). Why do so many young American men commit crimes and what might we do about it?. Journal of Economic perspectives, 10(1), 25-42.

[17] Gottfredson, D. C. (1985). Youth employment, crime, and schooling: A longitudinal study of a national sample. Developmental Psychology, 21(3), 419.

[18] Gould, E. D., Weinberg, B. A., \& Mustard, D. B. (2002). Crime rates and local labor market opportunities in the United States: 1979-1997. Review of Economics and statistics, 84(1), 45-61.

[19] Grogger, J. (1998). Market wages and youth crime. Journal of labor Economics, 16(4), 756-791.

[20] Grogger, J. (1998). Market wages and youth crime. Journal of labor Economics, 16(4), 756-791.

[21] Hamnett, C., \& Cross, D. (1998). Social change, social polarisation and income inequality in London, 1979-1993. GeoJournal, 46(1), 39-50.

[22] Hansen, K. (2003). Education and the crime-age profile. British Journal of Criminology, 43(1), 141-168.

[23] Herzer, D., \& Vollmer, S. (2012). Inequality and growth: evidence from panel cointegration. The Journal of Economic Inequality, 10(4), 489-503.

[24] Hjalmarsson, R. (2008). Criminal justice involvement and high school completion. Journal of Urban Economics, 63(2), 613-630.

[25] Levitt, S. D., \& Lochner, L. (2001). The determinants of juvenile crime. In Risky behavior among youths: An economic analysis (pp. 327-374). University of Chicago Press.

[26] Lindeboom, M., Llena-Nozal, A., \& van Der Klaauw, B. (2009). Parental education and child health: Evidence from a schooling reform. Journal of health Economics, 28(1), 109-131.

[27] Lochner, L. (2004). Education, work, and crime: A human capital approach. International Economic Review, 45(3), 811-843.

[28] Lochner, L. (2004). Education, work, and crime: A human capital approach. International Economic Review, 45(3), 811-843.

[29] Lochner, L. (2010). Non-Production Benefits of Education, forthcoming Chapter in Hanushek, E., S. Machin and L. Woessmann (eds.) Handbook of the Economics of Education.

[30] Lochner, L., \& Moretti, E. (2004). The effect of education on crime: Evidence from prison inmates, arrests, and self-reports. American economic review, 94(1), 155-189.

[31] Lochner, L., \& Moretti, E. (2004). The effect of education on crime: Evidence from prison inmates, arrests, and self-reports. American economic review, 94(1), 155-189.

[32] Machin, S., Marie, O., \& Vujić, S. (2011). The crime reducing effect of education. The Economic Journal, 121(552), 463-484.

[33] Machin, S., Marie, O., \& Vujić, S. (2011). The crime reducing effect of education. The Economic Journal, 121(552), 463-484.

[34] Machin, S., Marie, O., \& Vujić, S. (2011). The crime reducing effect of education. The Economic Journal, 121(552), 463-484.

[35] Meera, A. K., \& Jayakumar, M. D. (1995). Determinants of crime in a developing country: a regression model. Applied Economics, 27(5), 455-460.

[36] Megeri M.N., \& Kumar, G.M. (2015).Regression analysis of urbanization and social

[37] Meghir, C., \& Palme, M. (2005). Educational reform, ability, and family background. American Economic Review, 95(1), 414-424.

[38] Meghir, C., Palme, M., \& Schnabel, M. (2012). The effect of education policy on crime: an intergenerational perspective (No. w18145). National Bureau of Economic Research. 
[39] Messner, S. F., \& Sampson, R. J. (1991). The sex ratio, family disruption, and rates of violent crime: The paradox of demographic structure. Social Forces, 69(3), 693-713.

[40] Mustard, D. B. (2001). Racial, ethnic, and gender disparities in sentencing: Evidence from the US federal courts. The Journal of Law and Economics, 44(1), 285-314.

[41] polarization. International Journal of Recent Scientific Research. 6(8), 5922-5926

[42] Riddell, W. C., \& Song, X. (2011). The impact of education on unemployment incidence and reemployment success: Evidence from the US labour market. Labour Economics, 18(4), 453-463.

[43] Stephen, M., Olivier, M., \& Sunčica, V. (2012). Youth crime and education expansion (No. 009). Maastricht University, Research Centre for Education and the Labour Market (ROA).

[44] Vicente, G., Goicoa, T., Fernandez-Rasines, P., \& Ugarte, M. D. (2020). Crime against women in India: unveiling spatial patterns and temporal trends of dowry deaths in the districts of Uttar Pradesh. Journal of the Royal Statistical Society: Series A (Statistics in Society), 183(2), 655-679. 